\title{
A FORÇA ANCESTRAL FEMININA NO MAR DE IEMANJÁ - UM FOTOARTIGO
}

THE FEMALE ANCESTRAL FORCE IN THE YEMANJA SEA - A PHOTOARTICLE

\section{LA FUERZA ANCESTRAL FEMENINA EN EL MAR DE YEMANJA - UN ARTÍCULOFOTOGRÁFICO}

\section{Cristiano Sant'Anna ${ }^{1}$}

\begin{abstract}
Resumo
Pensar em fotografia é pensar em arte, é pensar em lembrança do vivido e do momento mágico eternizado em uma ou mais imagens. Cotidianamente, milhares de imagens são produzidas e circulam todos os dias nos vários meios de comunicação, seja na televisão, no cinema, nos espaços públicos e privados, nas redes sociais da internet, em nossa casa, nossa vida... Imagens estão, o tempo todo, à nossa volta, e constituem um dos mais importantes modos pelos quais vemos, aprendemos, pensamos, narramos e tecemos o presente. Pensando que as imagens estão a nossa volta e são potentes na nossa contemporaneidade, este artigo fotográfico aqui denominado de "fotoartigo", pretende trazer imagens fotográficas para homenagear a força ancestral feminina, representada aqui pela Orixá Iemanjá (Rainha do mar, mãe de todos os Orixás) Os Orixás são ancestrais africanos divinizados pelas forças da natureza tal como a água do mar, dos rios, das chuvas, dos raios, dos trovões, dos ventos... Orixá é força, é vida, é presente, é sabedoria, é conhecimento, é epistemologia do presente, passado e do futuro.
\end{abstract}

Palavras chave: Fotografia, Ancestralidade, Orixás

\begin{abstract}
To think of photography is to think of art, to think of the memory of the lived and the magic moment eternalized in one or more images. Every day, thousands of images are produced and circulated every day in the various media, whether on television, movies, public and private spaces, internet social networks, in our home, our lives ... Images are, the all around us, and constitute one of the most important ways in which we see, learn, think, narrate, and weave the present. Thinking that the images are around us and are potent in our contemporaneity, this photographic article here called "photoarticle", aims to bring photographic images to honor the female ancestral force, represented here by Orixá Iemanjá (Queen of the sea, mother of all Orixás) The Orixás are African ancestors deified by the forces of nature such as the water of the sea, rivers, rain, lightning, thunder, winds ... Orixá is strength, is life, is present, is wisdom, is knowledge, is epistemology of the present, past and future.
\end{abstract}

Submetido em: 31/08/2019 - Aceito em: 21/09/2019 - Publicado em: 28/12/2019.

${ }^{1}$ Doutor em Educação pelo PROPED/UERJ, Membro Pesquisador do Grupo Kékeré (pequeno em Yorubá) (CNPQ) e Professor da SEEDUC/RJ. E-mail: cs-medeiros@uol.com.br, RJ/Brasil 
Keywords: Photography, Ancestry, Orixás

Resumen

Pensar en la fotografía es pensar en el arte, pensar en el recuerdo de lo vivido y el momento mágico eterno en una o más imágenes. Todos los días, miles de imágenes se producen y circulan todos los días en los distintos medios, ya sea en televisión, películas, espacios públicos y privados, redes sociales de Internet, en nuestro hogar, nuestras vidas ... Las imágenes son, el a nuestro alrededor, y constituyen una de las formas más importantes en las que vemos, aprendemos, pensamos, narramos y tejimos el presente. Pensando que las imágenes nos rodean y son potentes en nuestra contemporaneidad, este artículo fotográfico aquí llamado "artículofotográfico", tiene como objetivo traer imágenes fotográficas para honrar la fuerza ancestral femenina, representada aquí por Orixá Yemanja (Reina del mar, madre de todos Orixás) Los Orixás son ancestros africanos divinizados por las fuerzas de la naturaleza, como el agua del mar, ríos, lluvia, rayos, truenos, vientos ... Orixá es fuerza, es vida, es presente, es sabiduría, es conocimiento, es epistemología del presente, pasado y futuro.

Palabras clave: Fotografía, Ascendencia, Orixás

\section{"Fotografia é poesia, visão da alma, sensibilidade de um artista. $O$ olhar do fotógrafo, mostra o seu interior" Mãe Nina de Oxum ${ }^{2}$}

Pensar em fotografia é pensar em arte, é pensar em lembrança do vivido e do momento mágico eternizado em uma ou mais imagens.

Cotidianamente, milhares de imagens são produzidas e circulam todos os dias nos vários meios de comunicação, seja na televisão, no cinema, nos espaços públicos e privados, nas redes sociais da internet, em nossa casa, nossa vida... Imagens estão, o tempo todo, à nossa volta, e constituem um dos mais importantes modos pelos quais vemos, aprendemos, pensamos, narramos e tecemos o presente.

Flusser (2011), autor de Filosofia da Caixa Preta e outros livros sobre imagem, nos aponta que as imagens são utilizadas para representar o mundo e também para nos orientar nele. As imagens tradicionais (pintura, escultura) e as imagens técnicas (fotografia, vídeo) têm algo em comum e cada uma tem seu impacto, que pode mudar conforme o tempo. Assim, para este autor, "o significado das imagens é o contexto mágico das relações reversíveis" (p. 23).

Entendemos, com Flusser (2011), que a imagem, principalmente a imagem técnica, é um artefato que produz e se articula, de alguma forma, com conceitos, às vezes hegemônicos, cuja produção está em parte inscrita na programação do aparelho e no universo fotográfico,

\footnotetext{
${ }^{2}$ Ialorixá (Mãe de Santo), sacerdotisa do Terreiro de Umbanda Cabana do Caboclo Pena Verde, RJ-Brasil
} 
resultando em imagens-clichê que circulam dogmaticamente na nossa sociedade, mas também, em determinadas circunstâncias, engendrando vidências outras que nos permitem vislumbrar novas possibilidades de percepção e pensamento.

Nas minhas relações com as imagens, tenho um apreço especial para com as fotografias. Elas me encantam, me fazem pensar, refletir, conhecer, estudar.

Desde o início da sua criação, a fotografia tem sido utilizada como prova do real, do que aconteceu, de que alguém esteve presente em um determinado local, dia ou hora. O nosso passado histórico pode ser comprovado pelas fotografias, a história das civilizações, os acontecimentos "verdadeiros"...

Nossa vida, desde a infância, a imagem de nossos pais e avós, nossos familiares, nossos antepassados, podem ser conhecidos através das fotos que são tiradas, reveladas, guardadas, coladas em álbuns, emolduradas; as lembranças do que vivemos, de onde fomos, com quem estivemos e queremos guardar, enfim, a nossa história pessoal em imagens.

Nisto corrobora Boris Kossoy (2009), com seu livro Fotografia e História:

A fotografia é indiscutivelmente um meio de conhecimento do passado, mas não reúne em seu conteúdo o conhecimento definitivo dele. A imagem fotográfica pode e deve ser utilizada como fonte histórica. Deve-se, entretanto ter em mente que o assunto registrado mostra apenas um fragmento da realidade, em um só enfoque da realidade passada: um aspecto determinado. Não é demais enfatizar que este conteúdo é o resultado final de uma seleção de possibilidades de ver, optar e fixar um certo aspecto da realidade primeira, cuja decisão cabe exclusivamente ao fotógrafo, quer esteja ele registrando o mundo para si mesmo, quer a serviço de seu contratante. (p. 113).

Kossoy (2009) também aponta quanto ao estudo de uma fotografia:

Toda fotografia tem atrás de si uma história. Olhar para uma fotografia do passado e refletir sobre a trajetória por ela percorrida é situá-la em pelo menos três estágios bem definidos que marcaram sua existência. Em primeiro lugar houve uma intenção para que ela existisse; esta pode ter partido do próprio fotógrafo que se viu motivado a registrar determinado tema do real ou de um terceiro que incumbiu para a tarefa. Em decorrência desta intenção teve lugar o segundo estágio: o ato do registro que deu origem à materialização da fotografia. Finalmente, o terceiro estágio: os caminhos percorridos por esta fotografia, as vicissitudes por que passou, as mãos que a dedicaram, os olhos que a viram, as emoções que despertou, os porta-retratos que a emolduraram, os álbuns que a guardaram, os porões e sótãos que a enterraram, as mãos que a salvaram. Neste caso seu conteúdo se manteve, nele o tempo parou. As expressões ainda são as mesmas. Apenas o artefato, no seu todo, envelheceu. (p. 45). 
Realmente, essas são algumas curiosidades que me vejo pensando ou até intrigando quando me deparo com uma determinada fotografia ou com as tantas fotografias que vemos cotidianamente em nossas redes de significações, nas redes que tecemos (ALVES, 2008).

Todas essas imagens fazem parte da nossa memória, que pode ser coletiva ou individual, mas que fazem a nossa história, e as observações acerca de cada uma, são as mais diversas possíveis.

Ainda com Flusser (2011), cuja "filosofia da caixa preta" são ensaios para uma filosofia da fotografia e, como explicamos anteriormente, fotografias são denominadas "imagens técnicas":

Trata-se de imagem produzida por aparelhos. Aparelhos são produtos da técnica que, por sua vez, é texto científico aplicado. Imagens técnicas são, portanto, produtos indiretos de textos - o que lhes confere posição histórica e ontológica diferente das imagens tradicionais. (Ibid., p. 29).

Essas imagens técnicas "imaginam textos que concebem imagens que imaginam o mundo" (Flusser,2011, p.30). Com isso, podemos imaginar o mundo não para modificá-lo, mas para que possamos criar os nossos próprios conceitos em relação ao mundo, àquilo que nos cerca, seja próximo ou distante, sem uma relação direta com textos apresentados ou atrelados a uma imagem, como no passado.

[...] as imagens técnicas (e, em primeiro lugar, a fotografia) deviam constituir um denominador comum entre conhecimento científico, experiência artística e vivência política de todos os dias. Toda imagem técnica devia ser, simultaneamente, conhecimento (verdade), vivência (beleza) e modelo de comportamento (bondade). [...] (Flusser,2011, p. 35. Grifo do autor).

Pensando que as imagens estão a nossa volta e são potentes na nossa contemporaneidade, seja na produção de fotos e vídeos ou no compartilhamento nas redes socias da internet, na nossa "Sociedade do Compartilhamento" (SANT'ANNA, 2017) ${ }^{3}$, este

\footnotetext{
${ }^{3}$ SANT'ANNA, Cristiano. \#Diferença: pensando com imagens dentrofora da escola. Tese de doutorado disponível em www.proped.pro.br
} 
artigo fotográfico que aqui denominamos "fotoartigo", pretende, trazer imagens, fotografias que tenho o hábito de fazer, todas de minha autoria, para que neste dossiê - "Mulheres Negras: epistemologias do presente", possamos homenagear a força ancestral feminina, representada aqui pela Orixá, Iemanjá ${ }^{4}$ (Rainha do mar, mãe de todos os Orixás).

Os Orixás são ancestrais africanos divinizados pelas forças da natureza tal como a água do mar, dos rios, das chuvas, dos raios, dos trovões, dos ventos... trazidos pelo processo da diáspora Africana ao redor do mundo, bem como aqui no Brasil, sendo cultuados e sobrevivendo na nossa cultura. Orixá é força, é vida, é presente, é sabedoria, é conhecimento, é epistemologia do presente, passado e do futuro, cultuados nas religiões de matriz africana tal como Umbanda ${ }^{5}$ e Candomblé ${ }^{6}$.

Iemanjá é a água salgada que corre nos oceanos e chega a todos continentes, ligada à maternidade, é a grande mãe que protege seus filhos e as crianças em especial. É a senhora dos Oris (cabeça em iorubá) responsável pelas cabeças humanas: “Assim, todo ser humano é considerado filho de Oxalá, que fabrica o corpo, e de Iemanjá, que governa a cabeça, (...)" (Vallado, 2012, p.36)

Reginaldo Prandi (2001) aponta no seu livro Mitologia dos Orixás a lenda na qual "Iemanjá é nomeada protetora das cabeças", que transcrevo aqui:

Dia houve em que todos os deuses deveriam atender ao chamado de Olodumare para uma reunião. Iemanjá estava em casa matando um carneiro, quando Legba chegou para avisá-la do encontro. Apressada e com medo de atrasar-se e sem ter nada para levar de presente a Olodumare, Iemanjá carregou consigo a cabeça do carneiro como oferenda para o grande pai. Ao ver que somente Iemanjá trazia-lhe um presente, Olodumare declarou: “Awoyó orí dorí re" "Cabeça trazes, cabeça serás." Desde então Iemanjá é a senhora de todas as cabeças (p.388)

\footnotetext{
${ }^{4}$ Yemojá - Divindade das águas do mar < yèyé+omo+ejá - Dicionário Yorubá Português

${ }^{5}$ A Umbanda é uma religião brasileira que sintetiza vários elementos das religiões africanas e cristãs, porém sem ser definida por eles. Formada no início do século XX no sudeste do Brasil a partir da síntese com movimentos religiosos como o Candomblé, o Catolicismo e o Espiritismo.

${ }^{6}$ Religião animista, original da região das atuais Nigéria e Benin, trazida para o Brasil por africanos escravizados e aqui estabelecida, na qual sacerdotes e adeptos encenam, em cerimônias públicas e privadas, uma convivência com forças da natureza e ancestrais. O candomblé é uma religião africana trazida para o Brasil no período em que os negros desembarcaram para serem escravos. Nesse período, a Igreja Católica proibia o ritual africano e ainda tinha o apoio do governo, que julgava o ato como criminoso, por isso os escravos cultuavam seus Orixás, Inquices e Vodus omitindo-os em santos católicos.
} 
Esta Orixá está ligada diretamente a tudo que se relaciona com o mar; seja através de suas águas consideradas sagradas e purificadoras, seja pelo movimento das marés, seja pelas correntes marítimas e seja pelo movimento das ondas do mar, favorecendo desta forma, a devoção dos pescadores a essa figura marinha, denominada a "Rainha do Mar", a "Grande Mãe" que proporciona a pesca abundante e o sustento das famílias desses pescadores.

Segundo Vallado,2012: “Iemanjá é também associada a diferentes mães-d’água da mitologia indígena, sendo por isso mesmo chamada Iara, a Mãe - d’Água.” (p.37); "Iemanjá sempre será associada aos Filhos-Peixes, da qual é a venerável Mãe, conforme seu próprio nome.”, e ainda: (...) tornam possível declarar Iemanjá como o Orixá mais popular do Brasil, visto pelo povo do candomblé, pelo povo da umbanda, ou ainda pela sociedade como um todo (p.39).

Muitos são seus adeptos que que reverenciam a grande mãe em festividades ao longo do nosso litoral quer seja nas festividades de ano novo ou no dia 02 de fevereiro onde se comemora seu dia, levando presentes e depositando no mar seja para agradecer, pedir proteção ou alguma benção.

Por todos esses atributos e por toda minha devoção especial a essa Mãe maior que governa muitos Oris, protegendo e amparando seus filhos peixes, inclusive a mim, que essa força ancestral feminina recebe a homenagem nas fotos que seguem neste "fotoartigo" num mar de mãe, num mar de mãe Iemanjá. Odoyá ${ }^{7} ! !$

\section{Mar de Iemanjá}

Iemajá sobá

Cinda mirerê

Iemajá sobá

Cinda mirerê

Cinda mirerê, Oi sobá!

Cinda mirerê

Cinda mirerê, Oi sobá!

Cinda mirerê

(Ponto de Umbanda)

\footnotetext{
${ }^{7}$ Saudação a lemanjá nas religiões de matriz africana (Umbamda e Candmblé)
} 


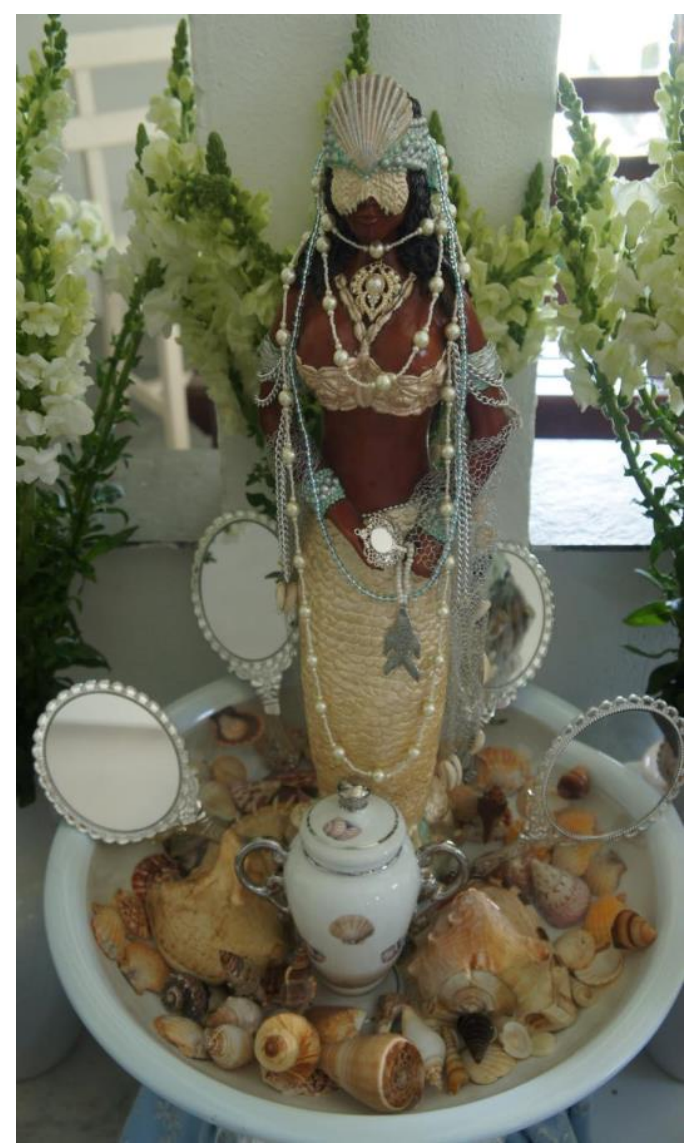

Dona da minha cabeça

Dentro das águas

Responde com o bem Odoyá!!

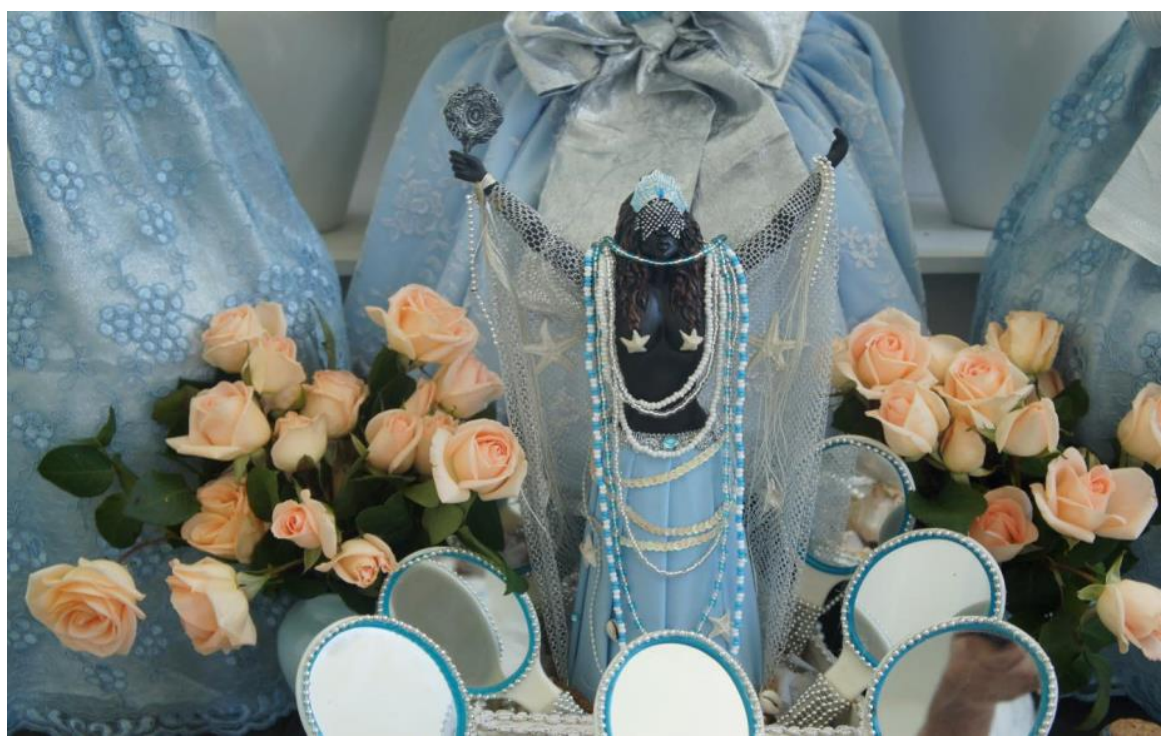




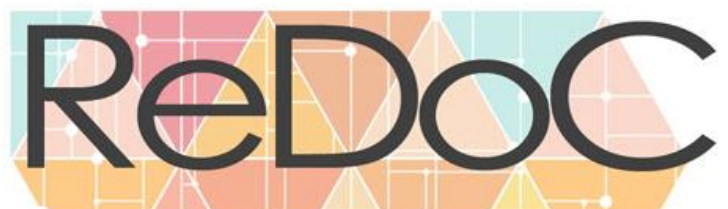

Revista Docência e Cibercultura

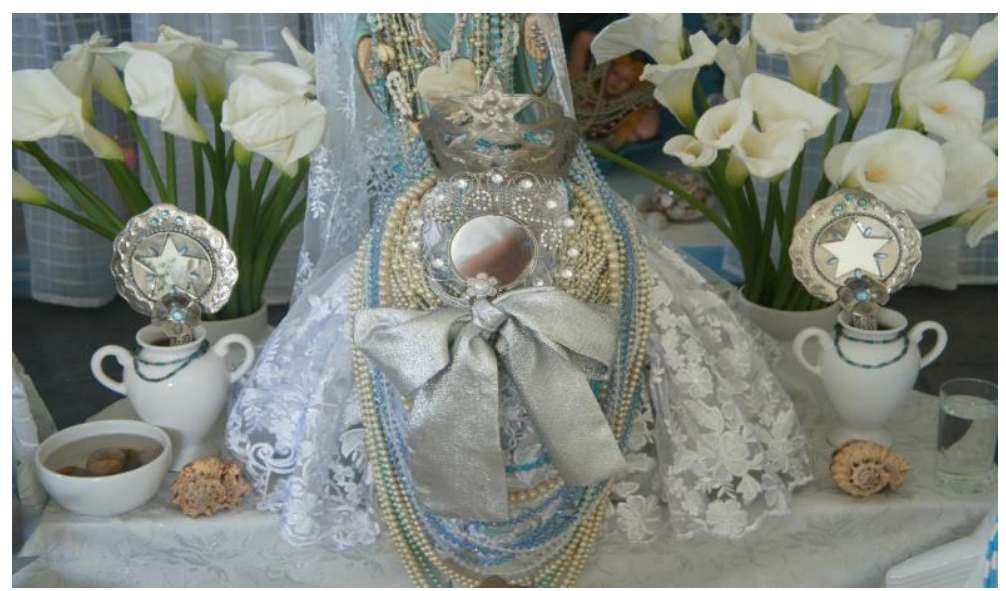

Na mais bela pérola, sua beleza encantada se revela.

Sua força de mãe, nas ondas do seu mar se entrega.

Mãe que ama, que acolhe, que ampara.

Mãe que adoça, que ergue e guarda.

Mãe dos filhos peixe, Mãe de todos os Orixás;

Mãe divina mãe, Mãe Yemanjá.

Odoyá!
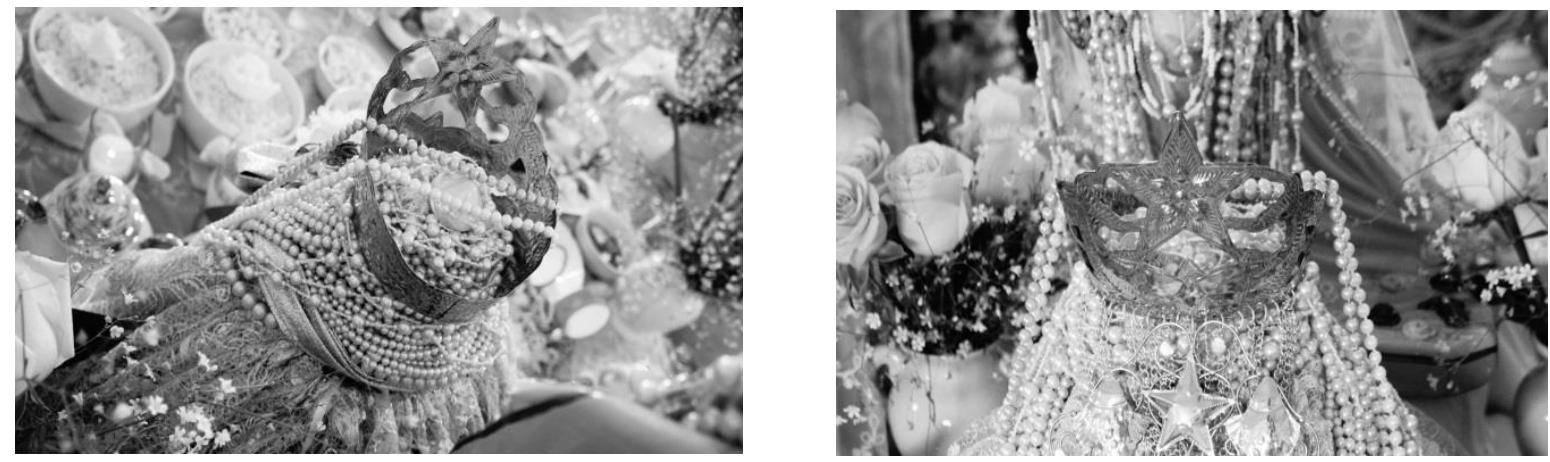

Iemanjá Iemanjá

É uma linda sereia que brinca na areia

Nas ondas do mar

Todos os domingos

Os pescadores trazem flores brancas para o mar

Pra mamãe Iemanjá êê

Pra mamãe Iemanjá (Ponto de Umbanda) 

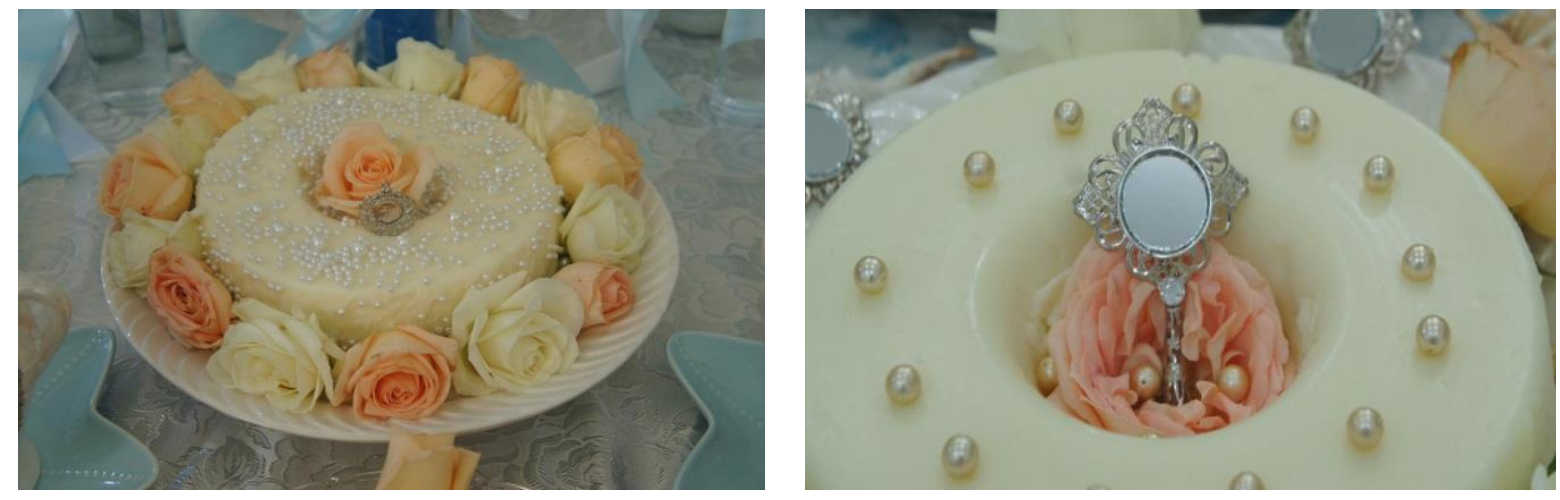

\section{Iemanjá}

Doce como um manjar

Ornamentado para lhe ofertar
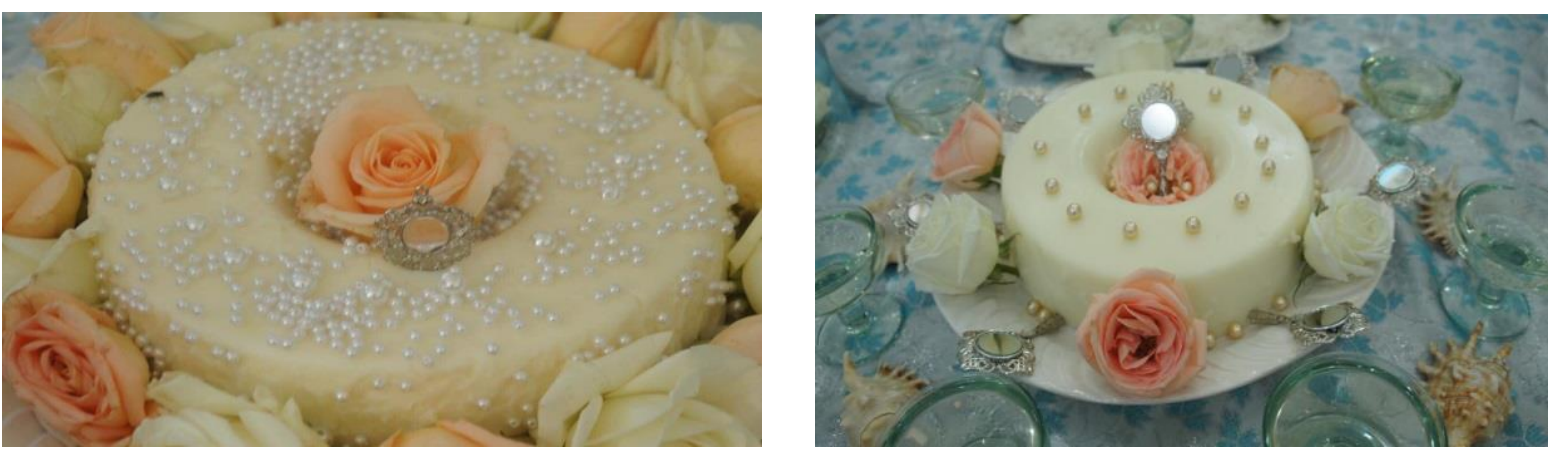

Pérolas são do seu mar

Todas brilhantes

Para lhe enfeitar
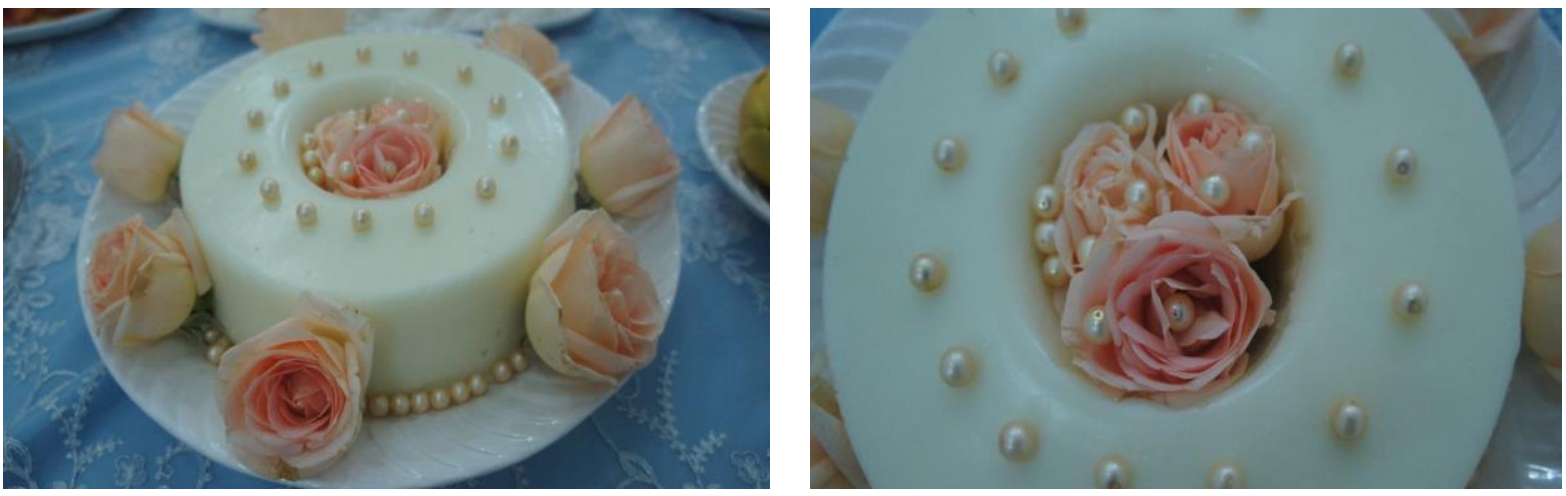

v. 3

n. 3

p. 279 


\author{
A luz dessa Yabá \\ Está em cada luar
}

Refletida nas ondas do mar

Para todos iluminar

Odociaba Iemanjá
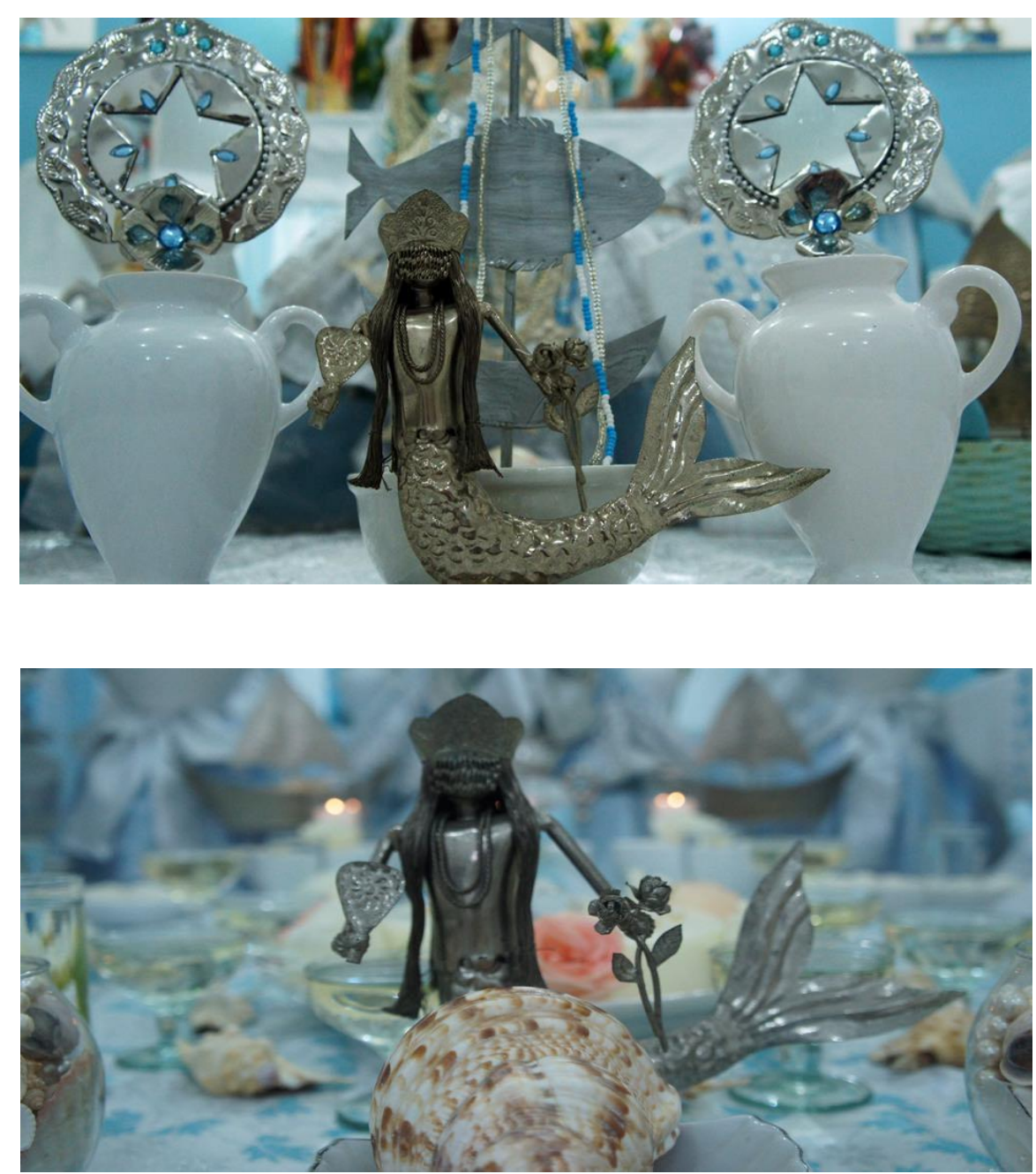

Rainha sereia do mar

O seu canto nos chama

Pela beleza que existe no seu mar

Faz o pescador se encantar

E seus filhos peixe abençoar 


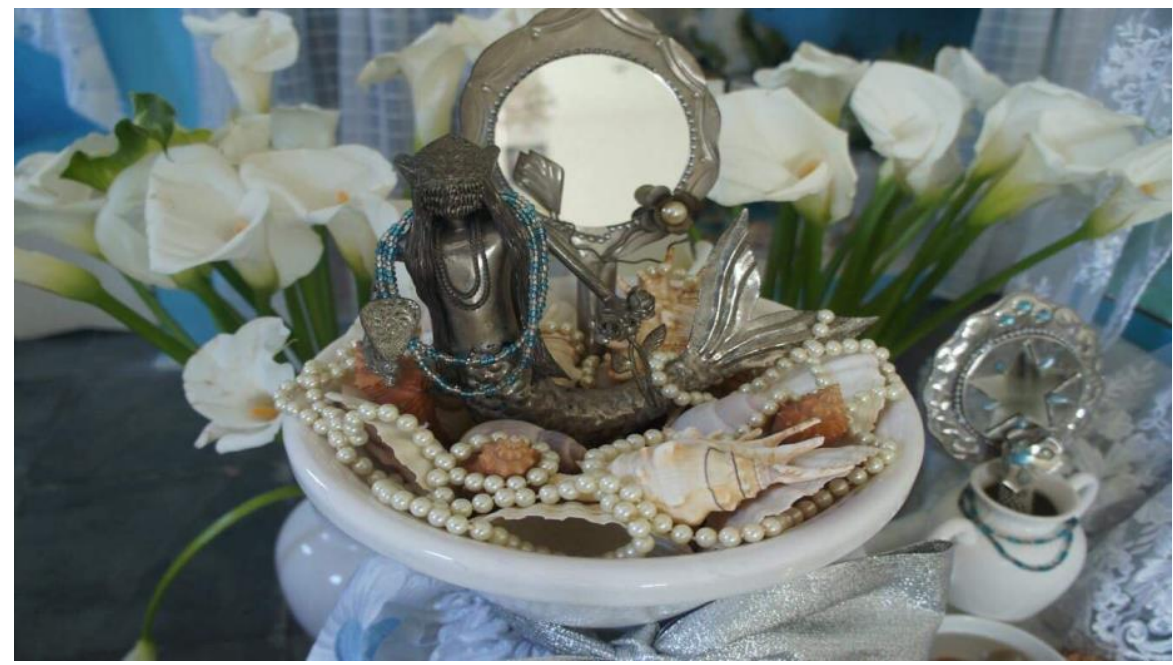

O mar serenou quando ela pisou na areia

Quem samba na beira do mar é sereia

O pescador não tem medo

É segredo se volta ou se fica no fundo do mar

Ao ver a morena bonita sambando

Se explica que não vai pesca (...) (Música de Antonio Candeia Filho)
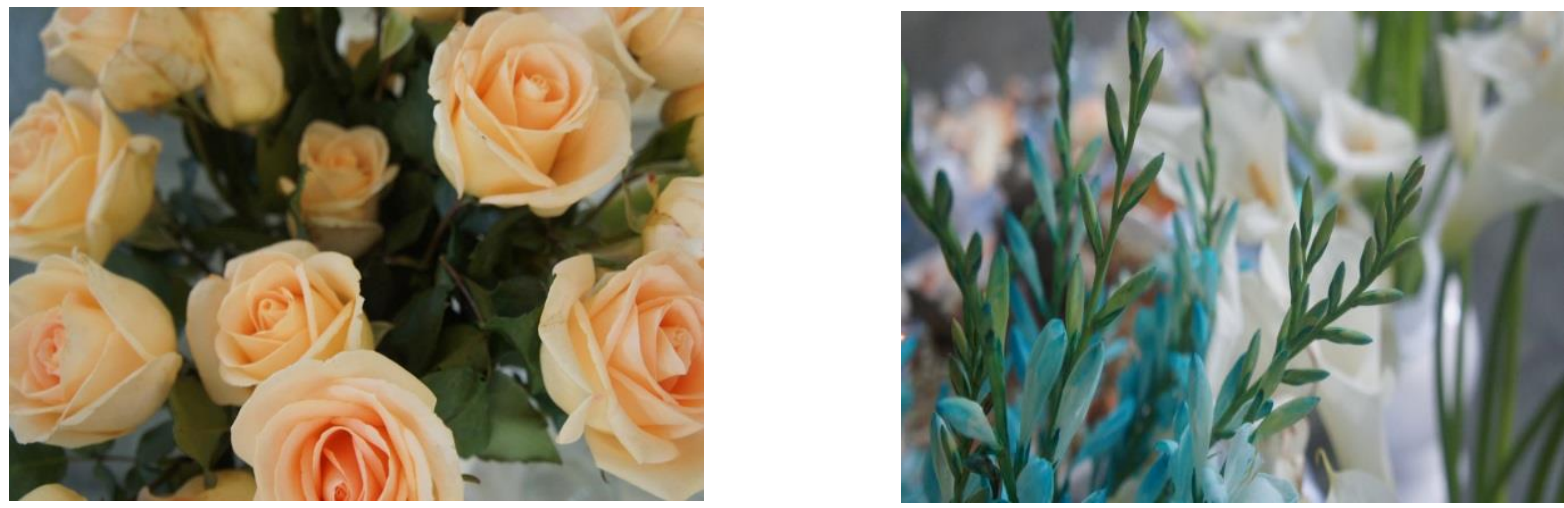

Trago flores pra lhe ofertar, oh grande Mãe do Mar

Palmas brancas, copos de leite, rosas brancas e rosas chá

Mãe amada, Rainha das águas sagradas

Mãe dos Orixás e das cabeças

Senhora dos tesouros da mente 
Soberana da calunga grande

Iemanjá, Janaína, Inaê, Sereia do mar
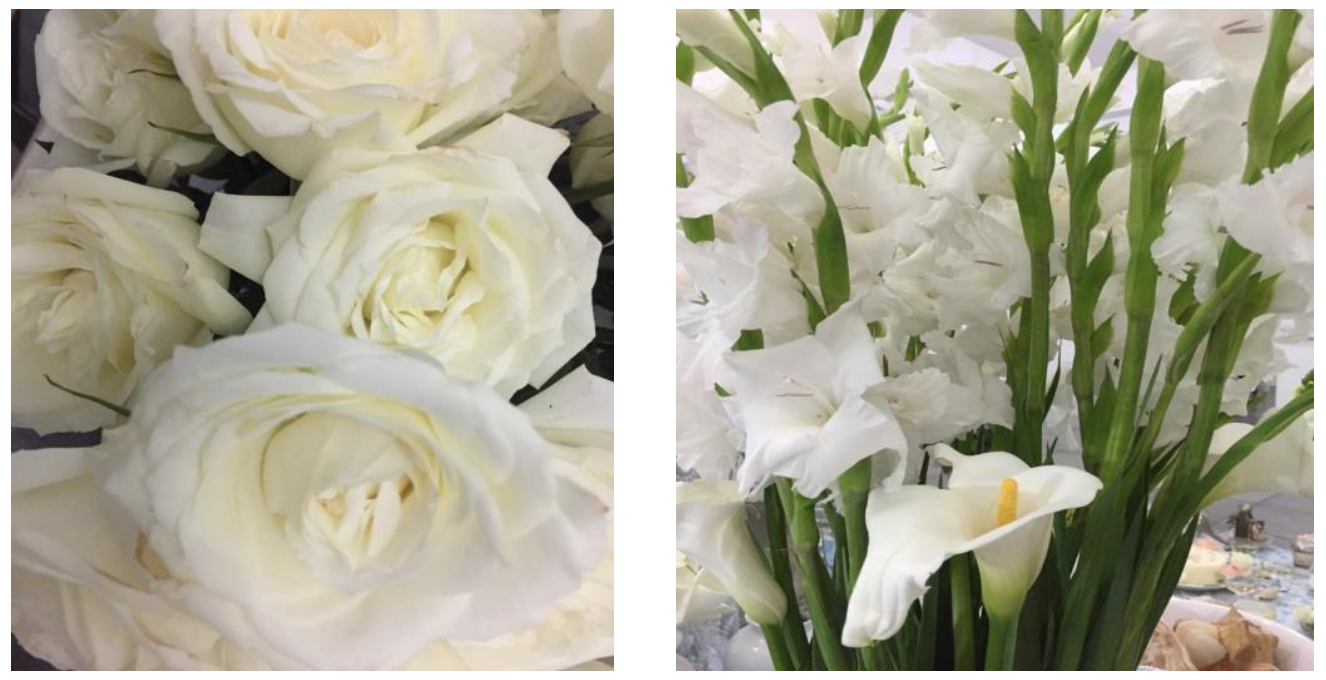

Oguntê, Marabô

Caiala, e sobá

Oloxum, Ynầ

Janaina e, Yemanjá

$O$ mar misterioso mar

Que vem do horizonte

É o berço das sereias

Lendário e fascinante

Olha o canto da sereia

Lalaó, oquê, ialoá

Em noite de lua cheia

Ouço a sereia cantar (...)

(Música de Arlindo Velloso / Dinoel Sampaio De Araujo / Vicente Paulo De Mattos)

Oceano é sua morada

Mergulhar nas águas sagradas

Cada gota abençoada

Pela grande Rainha do Mar 


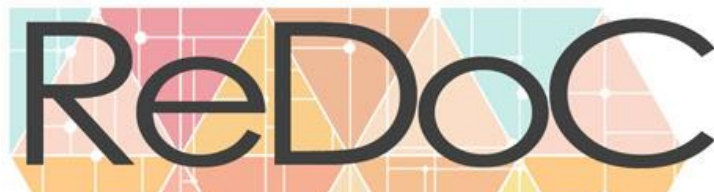

Revista Docência e Cibercultura
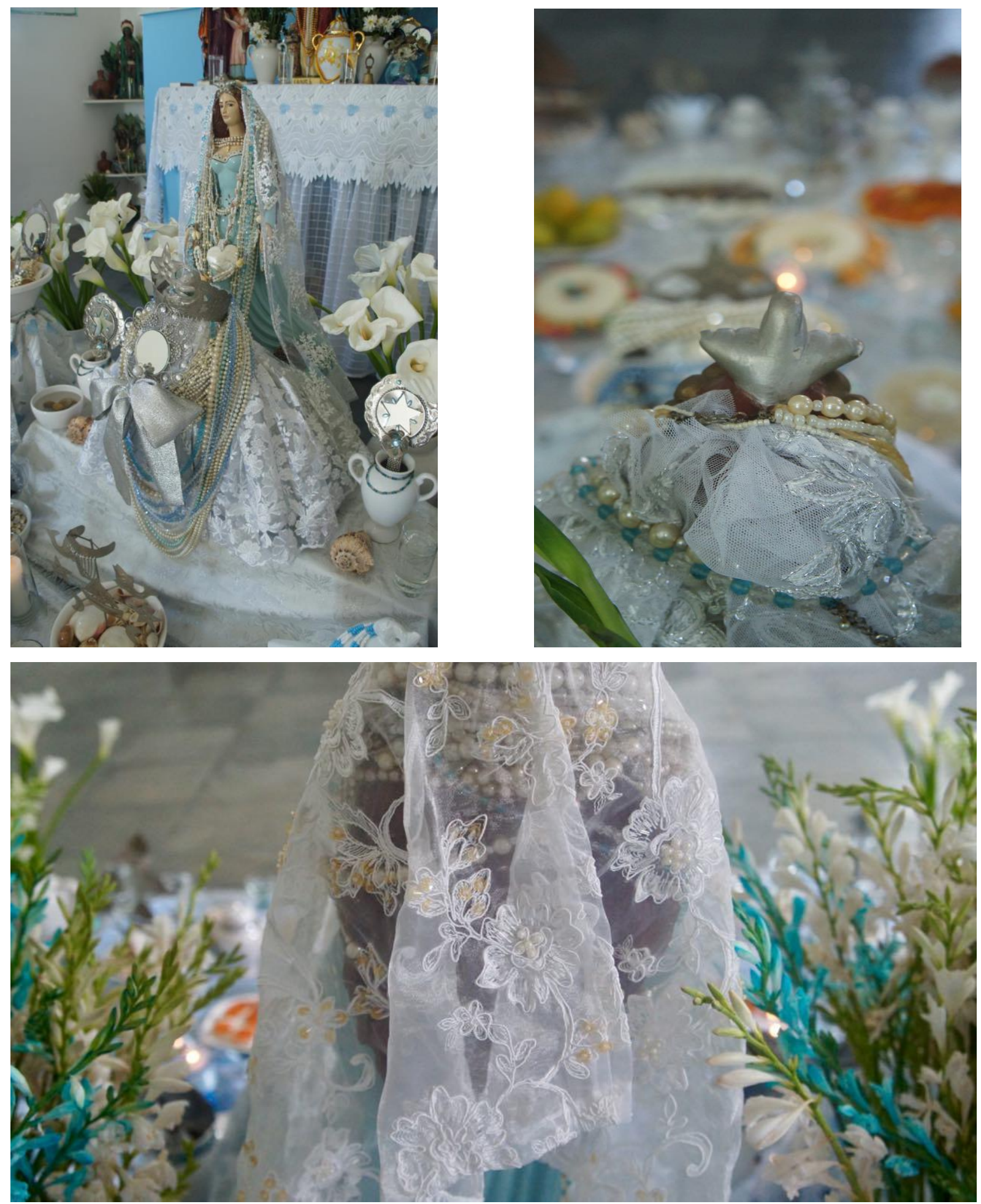


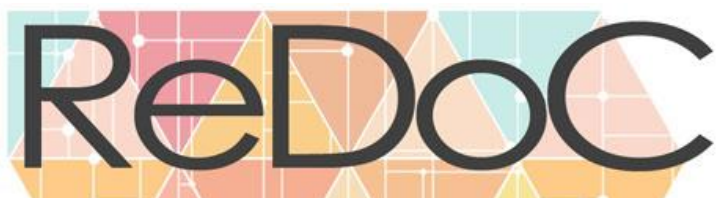

Revista Docência e Cibercultura
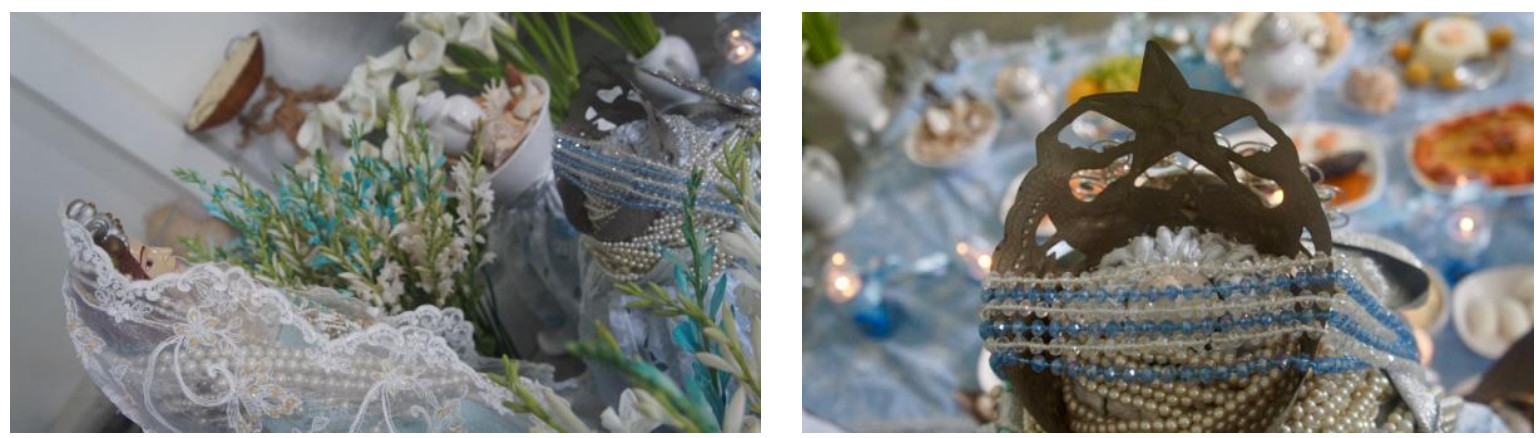

Seja coroa ou adê

Contas e pérolas

Estrela e conchas

Búzios e corais

Realeza do mar

Guarda as belezas

Salve a Rainha das águas salgadas
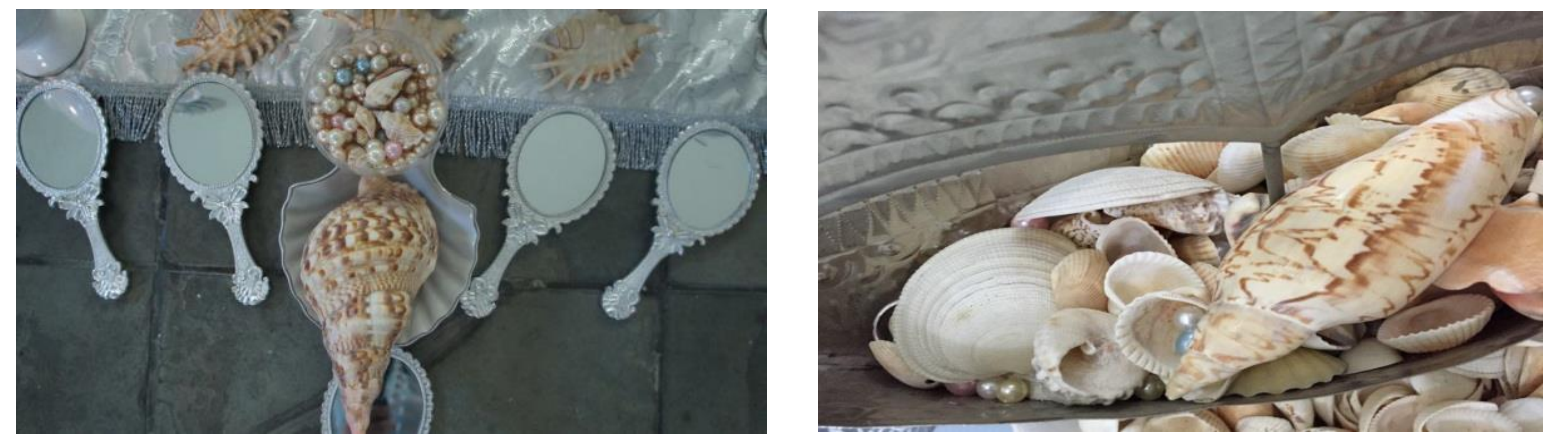

Dona dos Oris, Iyá mi

Peço sua benção e seu Axé

Saravá, Motumbá, Mukuiu, Kolofé

Minha eterna gratidão

Por esse mar de proteção

Odoyá!!! 


\section{Revista Docência e Cibercultura}

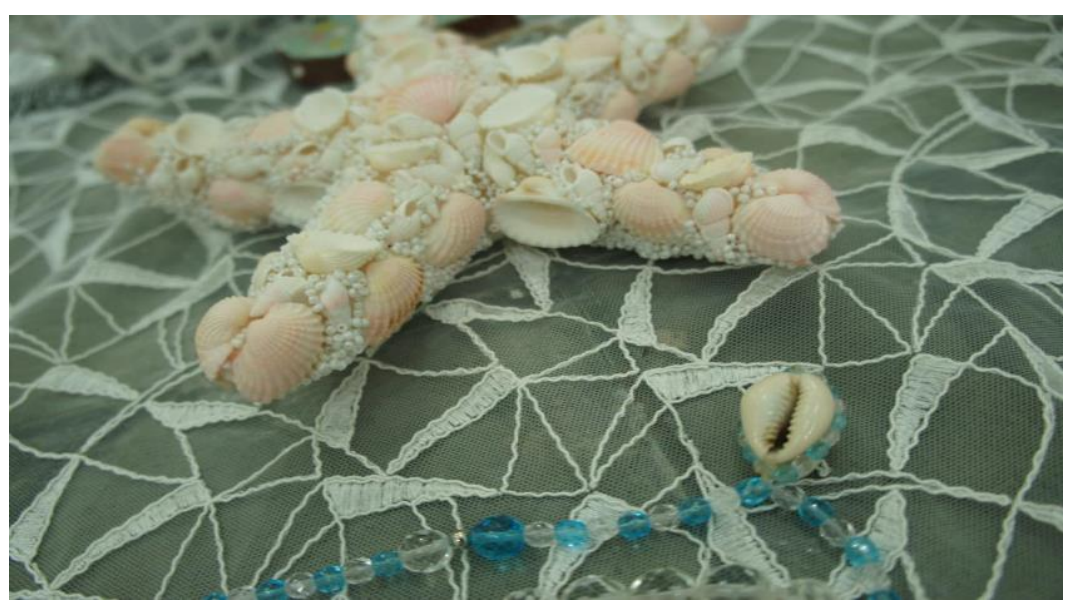

\section{REFERÊECIAS:}

ALVES, Nilda. Decifrando o pergaminho: os cotidianos das escolas nas lógicas das redes cotidianas. In: ALVES, Nilda; OLIVEIRA, Inês B. de (Orgs.). Pesquisa nos/dos/com os cotidianos das escolas. 3. ed. Petrópolis, RJ: DP, 2008, p. 15-38.

BENISTE, José. Dicionário Yorubá Português. Rio de Janeiro: Bertrand Brasil, 2011

FLUSSER, Vilém. Filosofia da Caixa Preta. São Paulo: ANNABLUME, 2011.

KOSSOY, Boris. Fotografia e História. 3 ed. São Paulo: Ateliê, 2009.

PRANDI, Reginaldo. Mitologia dos Orixás. São Paulo: Companhia das letras, 2001

VALLADO, Armando. Iemanjá - a grande mãe africana do Brasil. Rio de Janeiro: Pallas, 2008 